${ }^{1}$ Department of Mechanical Engineering Technologies, Lviv Polytechnic National University, 12, S. Bandery Str., Lviv, Ukraine, E-mail: i.gryc@i.ua

\title{
GEARS WITH ASYMMETRIC TOOTH PROFILES AND NEW ALTERNATIVE METHOD OF THEIR MANUFACTURING
}

Received: November 15, 2017 / Revised: December 22, 2017 / Accepted: December 26, 2017

(C) Hrytsay I., 2017

Abstract. The article presents a new gears cutting process - radial circular generating method and describes its multiple benefits for manufacturers of transmissions. The overall increase of efficiency is realized due to using a simple tool and the conventional gear tool machine for cutting gears of different types. In particular, this new method was used for cutting gears with the asymmetric profiles of wheel teeth, which allows considerably amplifying power transmission density, increasing load capacity, and reducing size and weight.

Keywords: gear, tool, asymmetric profile, cutting, new method, bettering, flexibility, versatility, efficiency.

\section{Introduction}

The transport vehicles' spur gears operate at increased speeds and loads, hence the requirements for their operational parameters are constantly increasing. Successful designed technological solutions, which would be able to meet those requirements, will lead to weight and dimension reduction of the transport gearboxes as well as to the lowering of its cost production. Thus, the issue of the bettering the performance characteristics of high speed gear drives is still relevant.

Among some of the effective ways to achieve this goal is the teeth profiles modification. The matter of profile modification lays in a creation of the asymmetric profiles that are relative to their planes of symmetry. The research findings of the asymmetric tooth gears for aerospace propulsion derived by A. Kapelevich (USA) indicate significant increase of the load capacity and, potentially of the size and weight reduction [1]-[6].

The geometry and designs of asymmetric tooth gears are presented in Fig. 1. Asymmetric gears pairs are shown in Fig. 2.

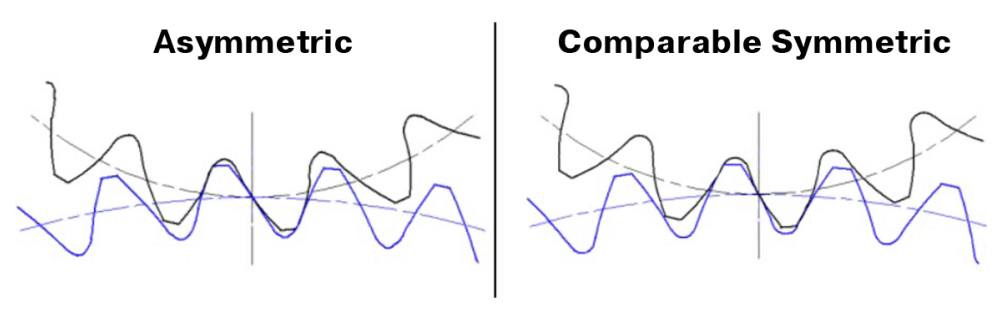

Fig. 1. Gears with asymmetric and symmetric teeth

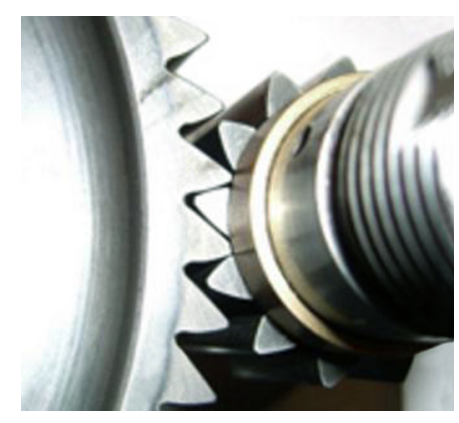

Fig. 2. Asymmetric gears pairs

However, the broad practical implementations of such gears are complicated since the asymmetric tooth gears require the dedicated cutter (hob) for each of the mating gears. A basic worm hob rack has a different flank angles of the left and the right side of the geartooth profile (Fig. 3). So each cutter is designed to cut a gear of one module and number of teeth. The main drawback of the hob design is that it makes a gear cutter manufacturing and grinding too complicated and expensive. Generally, this 
disadvantage is considered as a significant limitation for the wide practical utilization of the asymmetric tooth gears and such gearboxes.

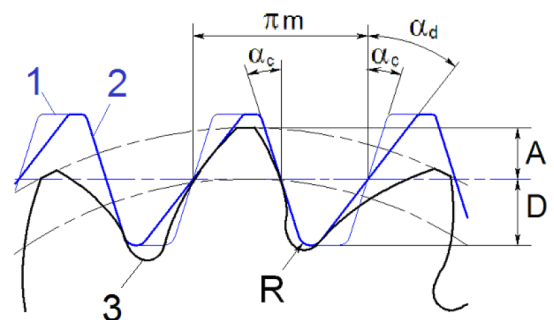

Fig. 3. Worm hob racks for cutting symmetric (1) and asymmetric (2) tooth gears [1]

Objective of the article is to offer the method of making gears with asymmetric profiles available for a wide range of applications.

\section{Methods and Materials}

This problem can be effectively solved by applying the high-performance, universal and technically simple method of the gears cutting - radial circular generating method.

By using this technique, the cutting is a relatively simple process; however, this one goes beyond the traditional gear cutting processes and has no parallels in the gear processing practice.

The kinematics of radial circular generating method is analogous to the cylindrical gears cutting (hob-generating) method's cinematic. In gear processing the thin $(1.5-4 \mathrm{~mm})$ disk-type milling cutter is set on the conventional gear cutting machine instead of screw - type hob. Disc cutter moves across the longitudinal gear axis in feed, rotates with a cutting speed while the gear blank rotates continuously, in the same way as does the tool on conventional hob shaper. The difference is that the disc cutter is setting eccentrically, so its kinematic axis and geometrical axis don't match up, because of a circular motion of cutter geometrical axis. As a result, the disc milling cutter is running simultaneously with periodic reciprocating movement. The magnitude of the eccentricity casts the value of the gear module [7]-[11].

The scheme of generating cutting and forming process with the radial circular generating method from a gear face is shown in Fig. 4.

Each top of the instrument tooth with regard to the centre of rotation (spindle axis) of technological mandrel describes a circular trajectory of a certain radius. Trajectories of movement of each tooth's tops of disc-type cutter are different, as well as the distances from the top of a particular tooth's to the spindle axis. At this case, the coordinates of tooth profile are described by the system of parametric equations:

$$
\left\{\begin{array}{l}
x_{D_{-} C}=\left(\frac{m \cdot Z_{G}}{2}+e \cdot \cos \varphi_{D_{-} C}\right) \cdot \cos \frac{\varphi_{D_{-} C}}{Z_{G}} \\
y_{D_{-} C}=\left(\frac{m \cdot Z_{G}}{2}+e \cdot \cos \varphi_{D_{-} C}\right) \cdot \sin \frac{\varphi_{D_{-} C}}{Z_{G}},
\end{array}\right.
$$

where $\varphi_{D_{-} C}$ is the angle of rotation disc mill cutter; $m$ and $Z_{G}$ are the module and the number of teeth of the gear, correspondingly; $e$ - magnitude of eccentricity.

As follows from the above equations, the gear teeth profiles do not depend on radius of the disk milling cutter.

The cutting tool is a thin disc milling cutter with a number of straight-sided speed steels or with ceramic/cermet inserted teeth (Fig. 5). Compared with complicated and expensive hob gear cutters, it has significant advantages: low cost; high revolution, cutting speed and feed; short milling time; no 
sharpening, high smoothness; high cutting ability; various profiles of gear tooth; high dimensional accuracy; fine surface finish; exterior and internal teeth; no re-sharpen.

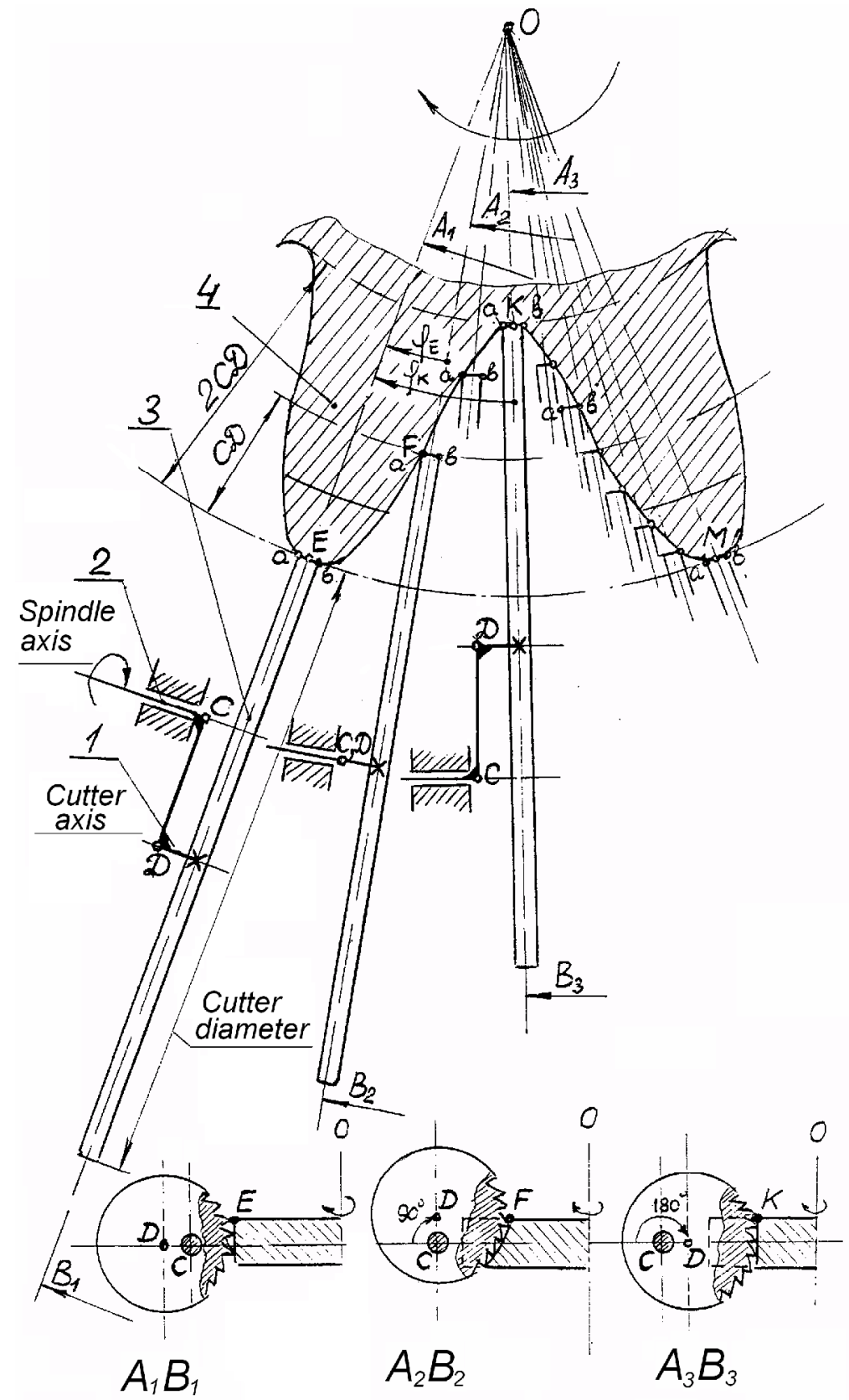

Fig. 4. Schematic illustration of gear generating cutting using the radial circular method

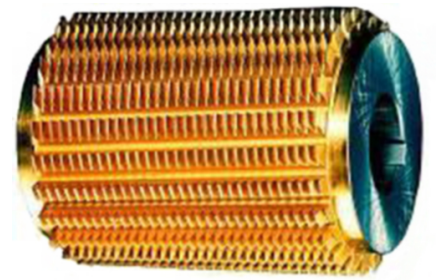

$a$

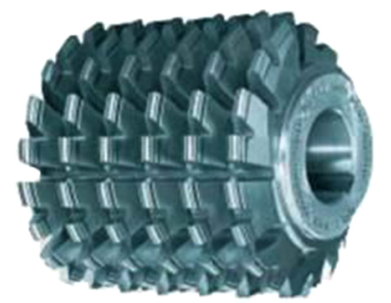

$b$
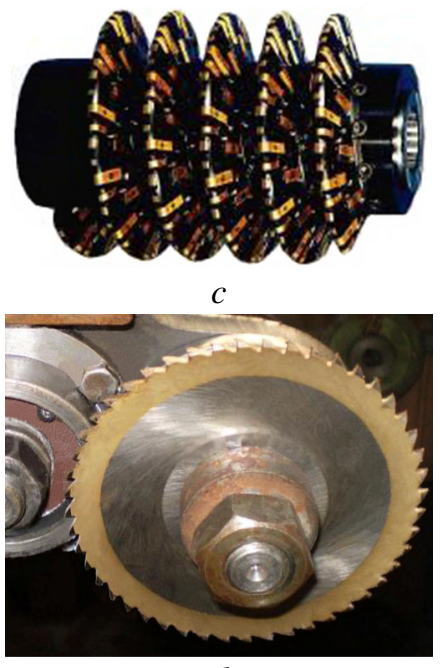

$d$

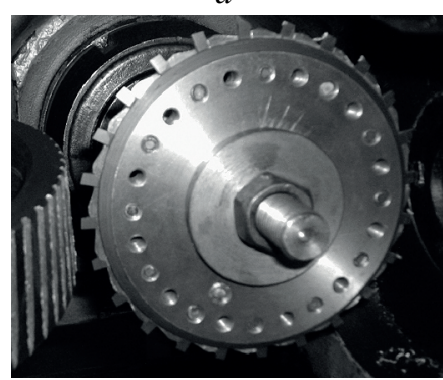

$e$

Fig. 5. Different types of hobs and disc milling cutters: a-monobloc gear hob;

$b$ - roughing-finishing multi hob; $c$ - indexable insert hob; $d$, e-disc milling cutters

The machine tool is a conventional gear-milling machine that operates on the same principle as hob gear machine tool does (Fig. 6). It's additional equipment is a cutter mandrel (Fig. 7). The elaborated mandrel design allows the flexibly change the eccentricity and module within the wide range $1-5 \mathrm{~mm}$. to flexible change the magnitude of module, through eccentricity shift. Thus creating an opportunity to cut gears of the different modules using only one milling cutter. 


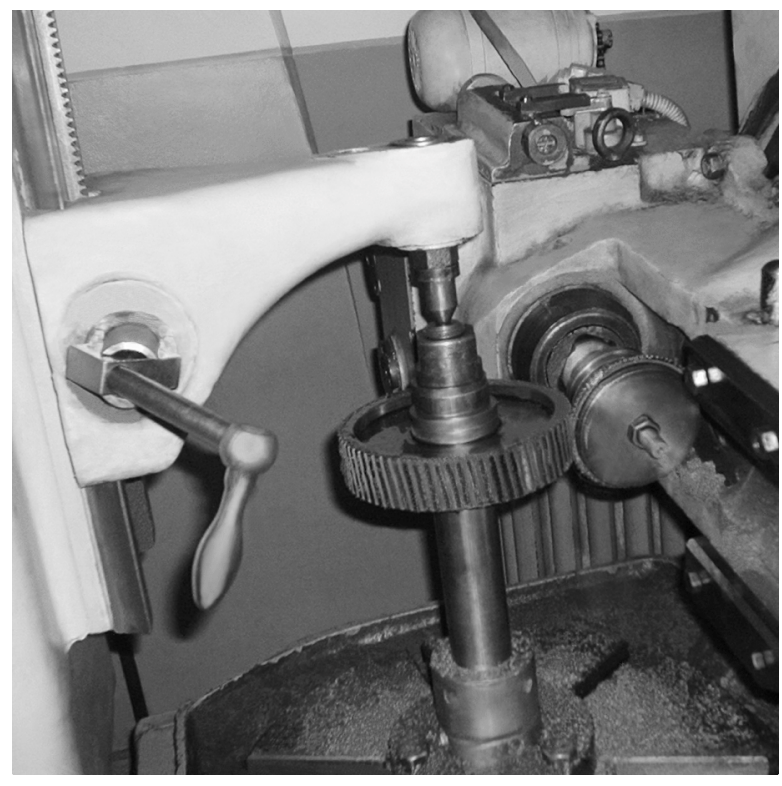

Fig. 6. Gear cutting machining using the radial circular generating method

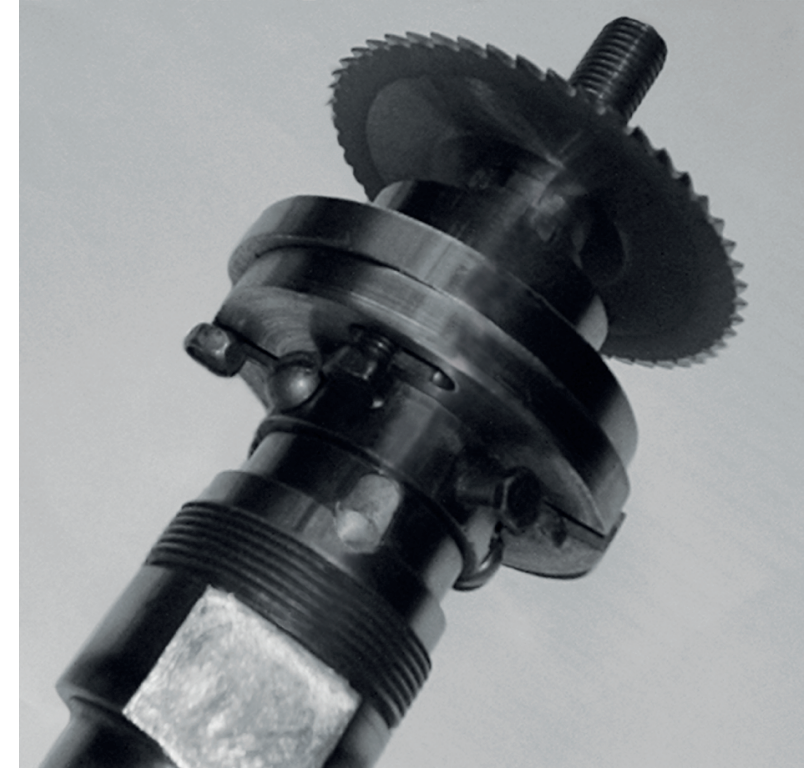

Fig. 7. Machine tool device to provide eccentricity on the disk mill cutter axis

In general, based on this method, using the conventional machine tool (gear-generating machine) and one thin disk mill cutter it is possible to generate different types and sizes of gears as well as to produce a variety of gears types. Its versatility is explained by the possibility to cut all gear types and various profiles including screw teeth gears (Fig. 8), exterior and internal teeth gears etc.
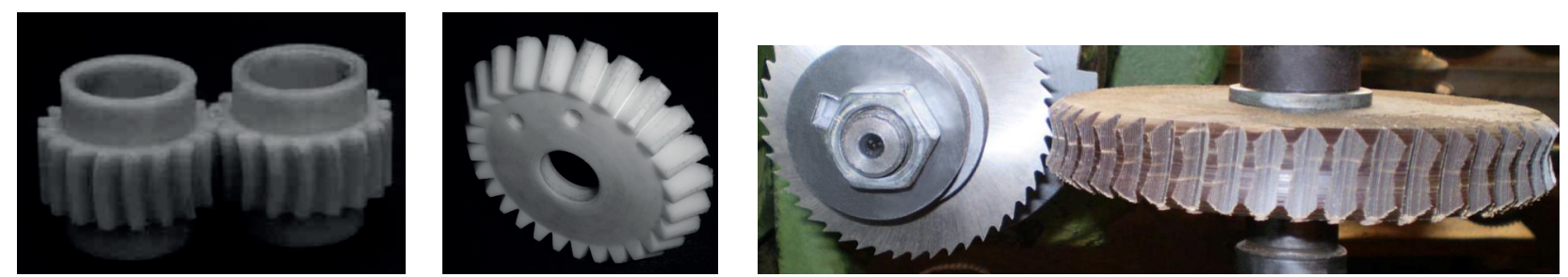

Fig. 8. Types of gears that can be made using a new method of gears cutting

\section{Results and Discussion}

In order to use this method for gears with the asymmetric tooth profiles to be machined, it is enough to relocate the disk cutter in the axial direction by a magnitude corresponding to the asymmetry of the profile (Fig. 9).

Typically, an asymmetric generating rack is modified from the standard symmetric rack by increasing the pressure angle of one flank. The opposite flank and other rack tooth proportions remain unchanged.

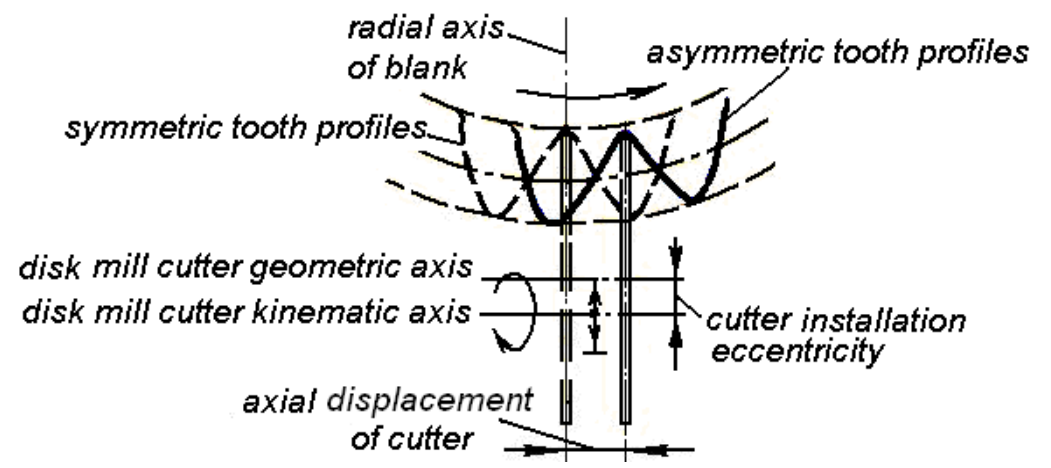

Fig. 9. Scheme of asymmetric profile teeth machining using the disc mill cutter 
The asymmetric tooth gears that are made in this way are presented in Fig. 10. Being produced by this method, the surface finish and dimensional accuracy of gear teeth are sufficient for its applications wile asymmetric gears do not require complicated special setup for this operation [4].
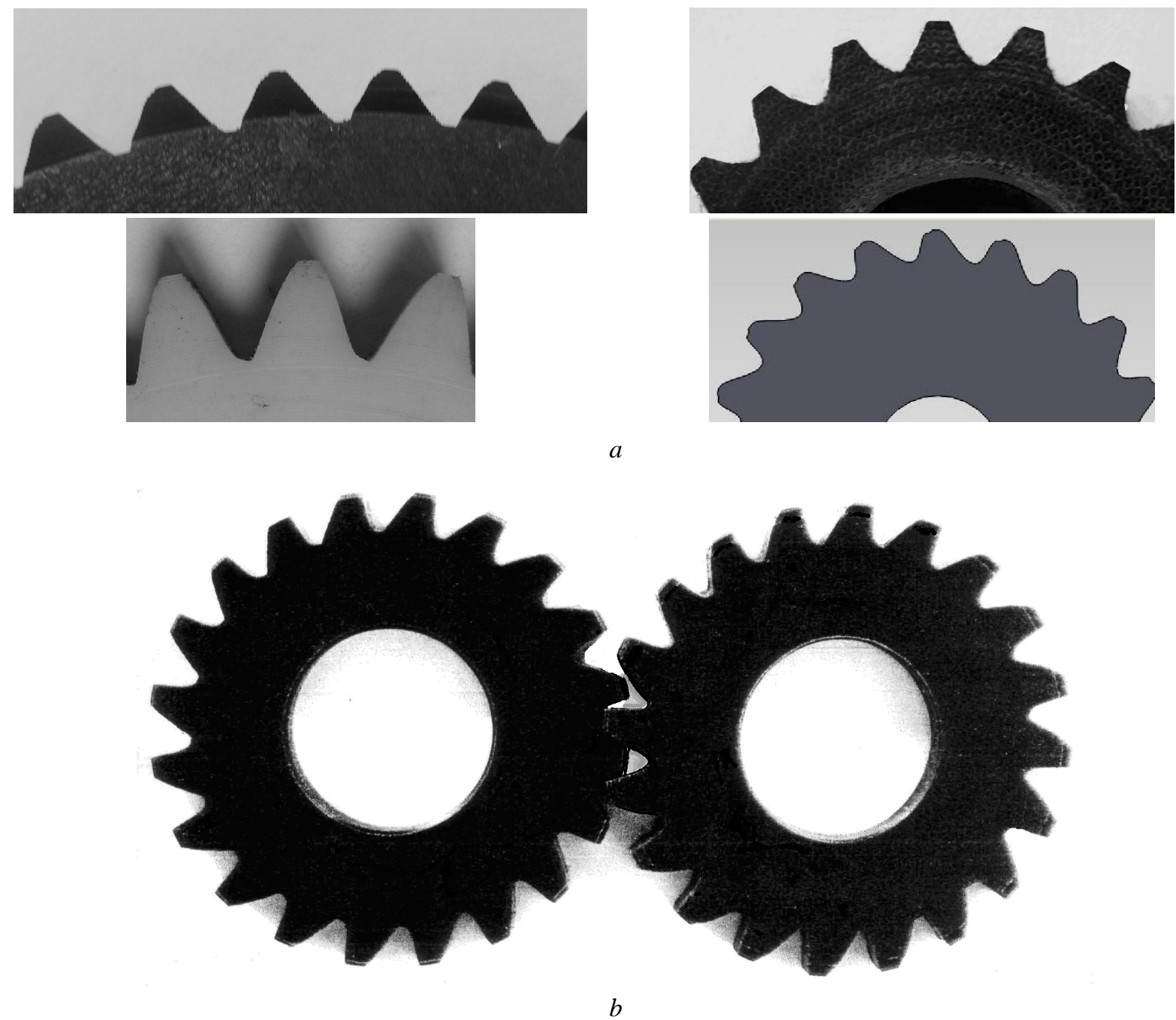

Fig. 10. Asymmetric tooth gears, which were cut using disc mill cutter with different modules and magnitude of asymmetric (a), and asymmetric tooth gear pair (b)

The equation that corresponds to the asymmetric tooth profiles is as follows:

$$
\left\{\begin{array}{l}
x_{D_{-} C}=\left(\frac{m \cdot Z_{G}}{2}+e \cdot \cos \varphi_{D_{-} C}\right) \cdot \cos \frac{\varphi_{D_{-} C}}{Z_{G}}-l \cdot \sin \varphi_{D_{-} C} ; \\
y_{D_{-} C}=\left(\frac{m \cdot Z_{G}}{2}+e \cdot \cos \varphi_{D_{-} C}\right) \cdot \sin \frac{\varphi_{D_{-} C}}{Z_{G}}-l \cdot \cos \varphi_{D_{-} C},
\end{array}\right.
$$

where $l$ is the magnitude of cutters displacement in the axial direction.

Consequently, the mentioned above cutting method of the asymmetric tooth gears boosts gear's load capacity, exceeds transmitting load and reduces contact strength within existing size and weight, increases the efficiency of gears manufacturing processes and can be widely applied.

\section{Conclusions}

A presented cutting method expands gears machining capabilities, versatility and flexibility of gearing, allows to reduce the number of expensive and complex gears cutting tools and gears machining 
tools. At the same time, the method makes it easy and efficient to cut gears with an asymmetric profile without using hobs for this purpose.

Consequently, the mentioned above cutting method enables to cut asymmetric teeth, possesses higher operational properties (amplifying power transmission density, increasing load capacity and reducing size and weight) using a consequential machines tool and simple cutting tools - thin disk mill cutter significantly reducing gear making processes costs.

\section{References}

[1] A. L. Kapelevich and Y. V. Shekhtman, Rating of Asymmetric Tooth Gears. Alexandria, Virginia: American Gear Manufacturers Association, 2015.

[2] A. L. Kapelevich, "Geometry and Design of Involute Spur Gears with Asymmetric Teeth", Mechanism and Machine Theory, vol. 35, pp. 117-130, 2000.

[3] A. L. Kapelevich, Direct Gear Design. Boca Raton: CRC Press, 2013.

[4] A. L. Kapelevich and Y. V. Shekhtman, "Tooth Fillet Profile Optimization for Gears with Symmetric and Asymmetric Teeth", Gear Technology, pp. 73-79, September/October, 2009.

[5] A. L. Kapelevich, "Asymmetric Gears: Parameter Selection Approach", Gear Technology, pp. 48-51, June/July 2011.

[6] A. S. Novikov et al., "Application of Gears with Asymmetric Teeth in Turboprop Engine Gearbox", in Proceedings of the 10th International ASME Power Transmission and Gearing Conference, Las Vegas, Nevada, USA, September 4-7, 2007, pp. 327-334.

[7] I. Ye. Hrytsay, A. M. Kuk and I. V. Klymash, "Doslidzhennia zubchastykh kolis z asymetrychnym profilem ta tekhnolohiia yikh vyhotovlennia radialno-kolovym sposobom" ["Research of gear wheels with asymmetric profile and technology of their manufacturing using radial-circular method"], in Proc. 6th Int. Conf. Progressive Technologies in Mechanical Engineering, Lviv, Ukraine, February 6-10, 2017, pp. 32-34. [in Ukrainian].

[8] S. Hromniuk and I. Hrytsai, "Cutter force and influence of elastic deformation of technological system of gear-hobbing machine on precision of radial-circumferential method of gear cutting," Ukrainian Journal of Mechanical Engineering and Materials Science, vol. 1, no. 2, pp. 67-74, 2015.

[9] I. Ye. Hrytsay and Ye. N. Blagut, "Zubchatye peredachi i tehnologii ih izgotovlenija: novoe v tradicionnom" ["Gear transmissions and technologies of their production: new in the traditional"], Oborudovanie $i$ instrument [Equipment and Tools], no. 2 (61), pp. 36-40, 2004. (in Russian).

[10] I. Ye. Hrytsay and Ya. M. Lytvyniak, "Synusoidalni zubchasti peredachi yak alternatyva tradytsiinym peredacham ta novyi metod yikh vyhotovlennia" ["Sinusoidal gear transmissions as an alternative to traditional transmissions and new method of their production"], Visnyk Natsionalnoho universytetu "Kharkivskyi politekhnichnyi instytut". Tematychnyi vypusk "Problemy mekhanichnoho pryvodu" [The Bulletin of NTU "KhPI". Series "Mechanical Drive Problems"], no. 19, pp. 43-53, 2009. (in Ukrainian).

[11] I. Ye. Hrytsay and S. I. Hromniuk, "Pidvyshchennia efektyvnosti protsesu narizannia zubchastykh kolis na osnovi radialno-obertovoho metodu v umovakh obkochuvannia" ["Improvement of efficiency of gear wheels cutting process on the basis of radial-rotating method in the conditions of grinding"], Nadiinist instrumentu ta optymizatsiia tekhnolohichnykh system [Reliability of the tool and optimisation of technological systems], vol. 32, pp. 226-229, 2013. (in Ukrainian). 